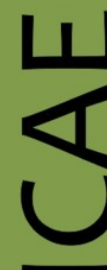

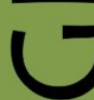

ex Instituto Archaeologico Universitatis de Rolando Eötvös nominatae

O

$\overrightarrow{0}$

山

$\leftarrow$

I

$\cup$

ه

$\leftarrow$

u

Ш

Z

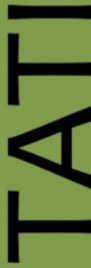

œ

ш

n

n

$\varnothing$
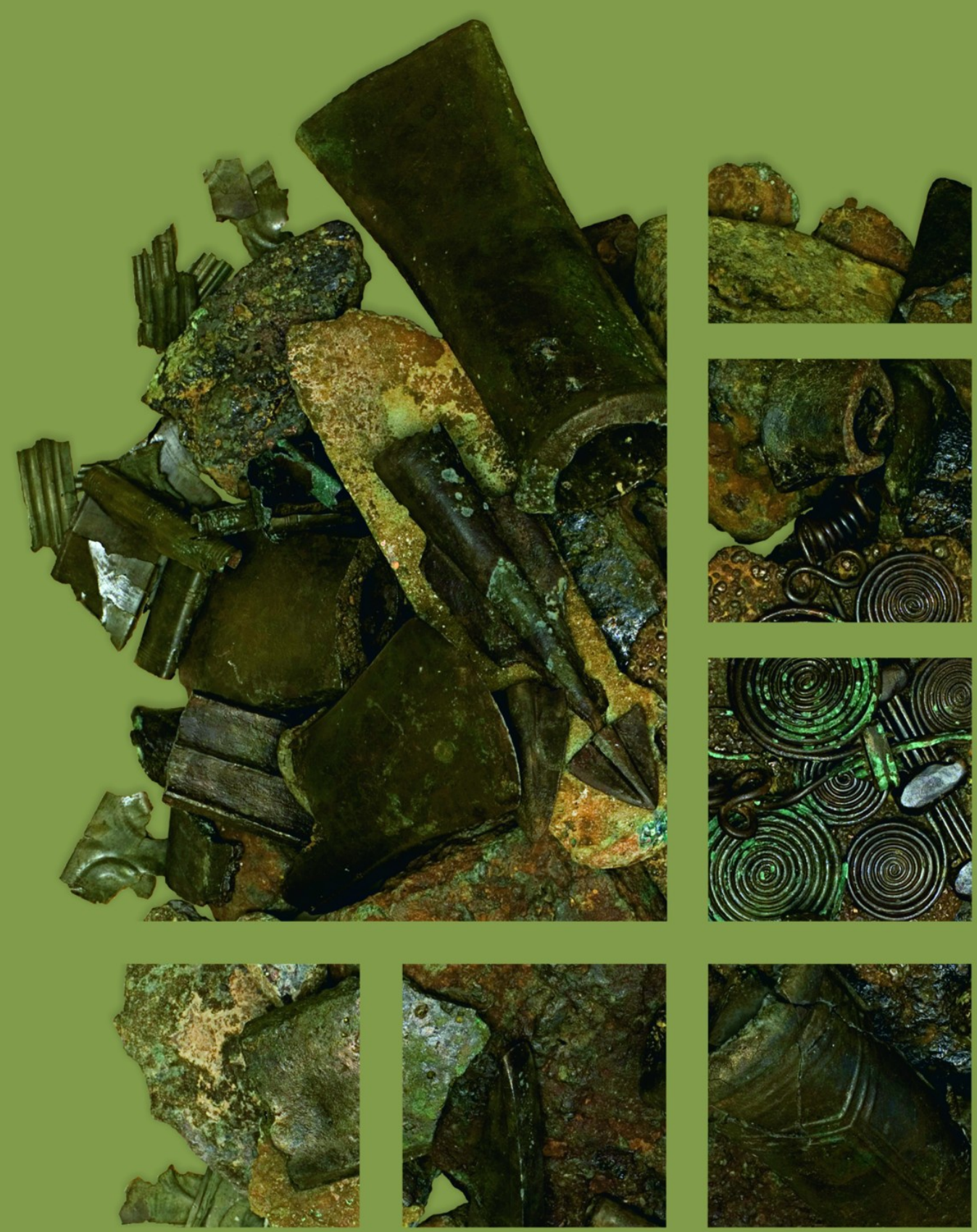


\section{Dissertationes Archaeologicae ex Instituto Archaeologico}

Universitatis de Rolando Eötvös nominatae Ser. 3. No. 2.

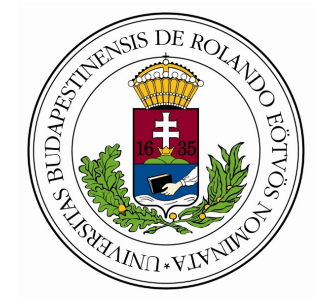

Budapest 2014 
Dissertationes Archaeologicae ex Instituto Archaeologico Universitatis de Rolando Eötvös nominatae

Ser. 3. No. 2.

Editor-in-chief:

DÁvid BARTus

Editorial board:

LÁsZló BARTOSIEWICZ

LÁSZLÓ BORHY

IsTVÁN FELD

GÁBOR KALLA

PÁL RACZKY

MiKLÓs SzABÓ

TIVADAR VIDA

Technical editors:

DÁvid BARTus

GÁBOR VÁCZI

ANDRÁs BÖDŐCS

DÁNIEL SZABÓ

Proofreading:

SZILVIA SzÖLLősI

Available online at http://dissarch.elte.hu Contact: dissarch@btk.elte.hu

$$
\begin{aligned}
& \text { PUBLIC } \\
& \text { KNOWLEDGE } \\
& \text { PROJECT }
\end{aligned}
$$

(c) Eötvös Loránd University, Institute of Archaeological Sciences

Budapest 2014 


\section{Contents}

\section{SElected PAPERS OF THE XI. Hungarian CONFERENCE on Classical Studies}

Ferenc BARNA

Venus mit Waffen. Die Darstellungen und die Rolle der Göttin in der Münzpropaganda

der Zeit der Soldatenkaiser (235-284 n. Chr.)

Dénes GABLER

A belsó vámok szerepe a rajnai és a dunai provinciák importált kerámiaspektrumában

Lajos MATHÉDESZ

Római bélyeges téglák a komáromi Duna Menti Múzeum gyújteményében

Katalin OtTOMÁNYI

Újabb római vicusok Aquincum territoriumán

Eszter SÜVEGH

Hellenistic grotesque terracotta figurines. Problems of iconographical interpretation

András SzABó

Some notes on the rings with sacred inscriptions from Pannonia

István VIDA

The coinage of Flavia Maxima Helena

\section{Articles}

Gábor TARBAY

Late Bronze Age depot from the foothills of the Pilis Mountains

Csilla SÁRó

Roman brooches from Paks-Gyapa - Rosti-puszta

András BöDőcs - Gábor KovÁcs - Krisztián ANDERKó

The impact of the roman agriculture on the territory of Savaria

Lajos JuHÁsz

Two new Roman bronzes with Suebian nodus from Brigetio

\section{FIELD REPORTS}

Zsolt MESTER - Norbert FARAGó - Attila KirÁLy

The first in situ Old Stone Age assemblage from the Rába Valley, Northwestern Hungary

Pál RACZky - Alexandra ANDERs - Norbert FARAgó - Gábor MÁRKus

Short report on the 2014 excavations at Polgár-Csőszhalom 
Preliminary Report on the first season of fieldwork in Berettyóúffalu-Szilhalom

Márton SzILÁgyi - András FüZESI - Attila VIRÁG - Mihály GASPARIK

A Palaeolithic mammoth bone deposit and a Late Copper Age Baden settlement and enclosure

Preliminary report on the rescue excavation at Szurdokpüspöki - Hosszú-dúlö II-III. (M21 site No. 6-7)

Kristóf FüLÖP - Gábor VÁcZI

Preliminary report on the excavation of a new Late Bronze Age cemetery

from fobbágyi (North Hungary)

Lőrinc TimÁr - Zoltán CzAJLik - András BöDőcs - Sándor PuszTA

Geophysical prospection on the Pâture du Couvent (Bibracte, France). The campaign of 2014

Dávid BARtus - László Borhy - Gabriella Delbó - Emese SzÁmadó

Short report on the excavations in the civil town of Brigetio (Szőny-Vásártér) in 2014

Dávid BARTus - László BorHy - Emese SzÁMADó

A new Roman bath in the canabae of Brigetio

Short report on the excavations at the site Szőny-Dunapart in 2014

Dávid BARTus - László Borhy - Zoltán CzAjlik - Balázs Holl -

Sándor PuszTA - László RuPNiK

Topographical research in the canabae of Brigetio in 2014

Zoltán CZAJLIK - Sándor BERECKI - László RUPNIK

Aerial Geoarchaeological Survey in the Valleys of the Mureș and Arieș Rivers (2009-2013)

Maxim MoRDovin

Short report on the excavations in 2014 of the Department of Hungarian Medieval

and Early Modern Archaeology (Eötvös Loránd University, Budapest)

Excavations at Castles Čabrad' and Drégely, and at the Pauline Friary at Sáska

\section{Thesis Abstracts}

Piroska Csengeri

Late groups of the Alföld Linear Pottery culture in north-eastern Hungary

New results of the research in Borsod-Abaúj-Zemplén County

Ádám Bíró

Weapons in the 10-11th century Carpathian Basin

Studies in weapon technology and methodology - rigid bow applications and southern import

swords in the archaeological material

Márta DARÓcZI-SzABó

Animal remains from the mid 12th-13th century (Árpád Period) village of Kána, Hungary

Károly BELÉNYESY

A 15th-16th century cannon foundry workshop in Buda

Craftsmen and technology of cannon moulding and the transformation of military technology

from the Renaissance to the Post Medieval Period 
István RINGER

Manorial and urban manufactories in the 17th century in Sárospatak

\section{BIBLIOGRAPHY}

László BORHY

565

Bibliography of the excavations in Brigetio (1992-2014) 


\title{
The coinage of Flavia Maxima Helena
}

ISTVÁN VIDA

Hungarian National Museum

vida.istvan@hnm.hu

\begin{abstract}
Three late Roman silver coins bearing the name Flavia Maxima Helena became known in the recent years. This study discusses their date and the background of the issue, and also identifies the person, whom the coins were minted to as Helena, wife of Julian II.
\end{abstract}

In March 2013 a very unusual late Roman silver coin (Fig. 1) was donated to the Hungarian National Museum. The alleged findspot is about halfway between Győr (Arrabona) and Komárom (Brigetio), 10-15 kilometres south of the River Danube.

Obv.: FLAV MAX - HELEN AVG

Diademed, draped bust right.

Rev.: AETER-NITAS

Fortuna standing left, holding globe and rudder.

The weight of the coin is $2.27 \mathrm{~g}$, the die axis is $12 \mathrm{~h}$.

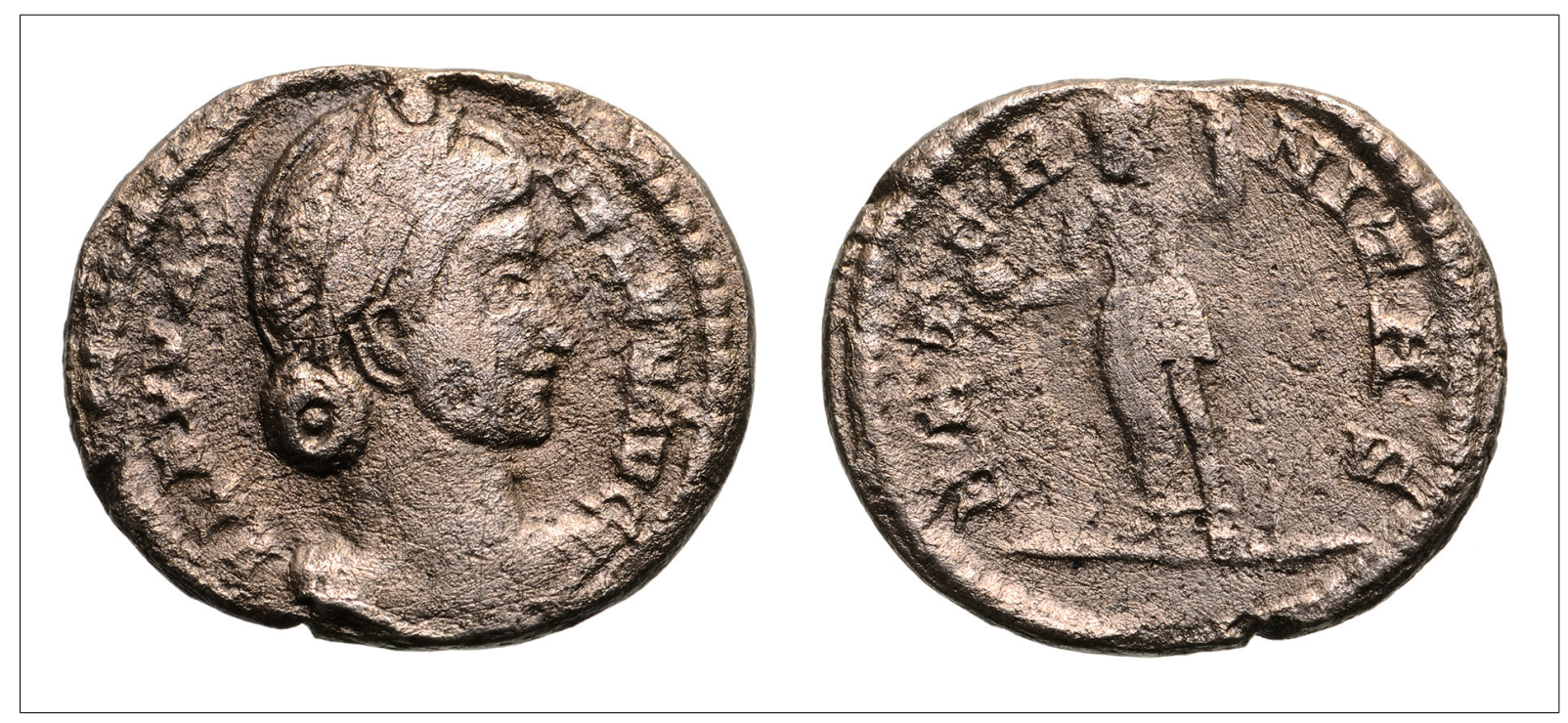

Fig. 1. Flavia Maxima Helena, siliqua, Budapest.

The coin was very peculiar, with a definitely 4 th century style. On the obverse a female member of the imperial family was depicted, but no person with the name Flavia Maxima Helena is known form the 4th or other centuries. Also the reverse is strange, as the depiction is known only from earlier times, not on 4th century coins. 


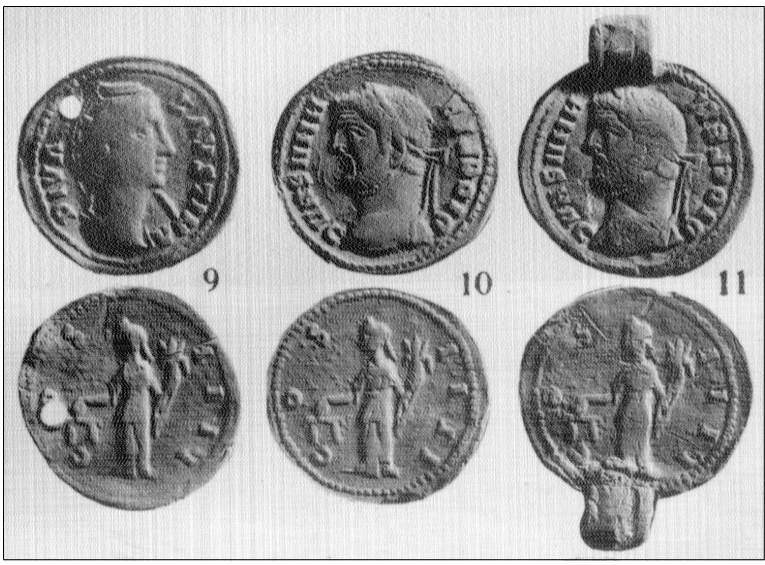

Fig. 2. Early 4th century imitations of aurei.

First I regarded the coin a contemporary imitation, and this seemed to solve the problem of the erroneous name and anachronistic depiction. Imitations sometimes copy issues minted decades or centuries earlier, for example there are early 4th century barbarous aurei imitating the coins of Faustina Maior ${ }^{1}$ and Diocletian ${ }^{2}$ struck with the same reverse die imitating a coin of Antoninus Pius (Fig 2). ${ }^{3}$ Presumably the trusted, good quality coins of earlier times were copied in this unsettled period. ${ }^{4}$ Thus I dated the coins to the first third of the 4th century, when - except for the time of the tetrarchy - there was no good quality silver coinage. The style of the silver coin, not yet cleaned at the time, did not fit into the period, but in the case of an imitation it did not seem to be a real problem. So I identified the empress as Helena, mother of Constantine I, though only gold and bronze coins of her are known, and assumed, that the name was given in error instead of Flavia Julia Helena.

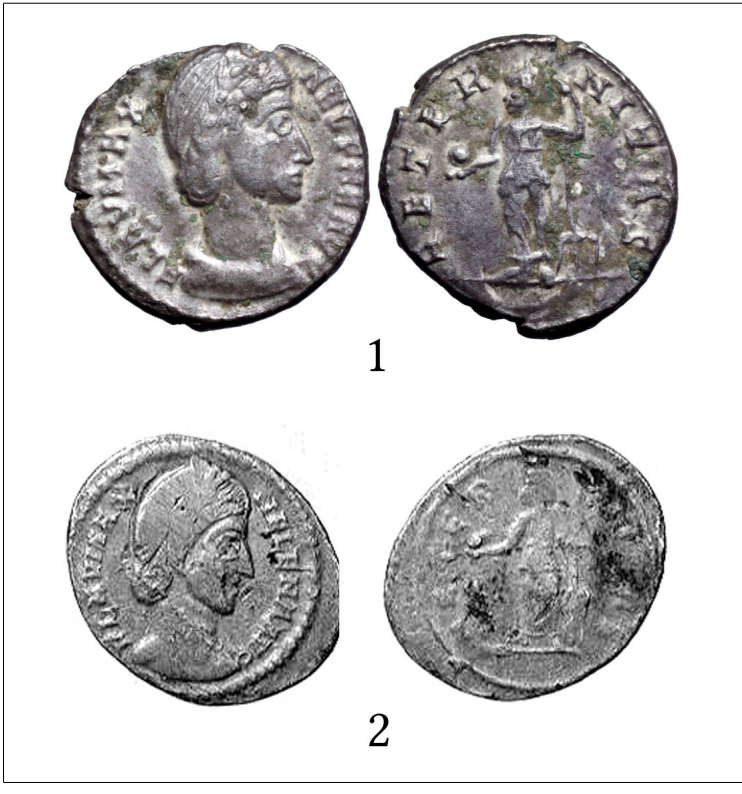

Fig. 3. 1. Flavia Maxima Helena, siliqua, London, courtesy of www.RomaNumismatics.com. 2. Flavia

Maxima Helena, siliqua, Madrid, courtesy of www.jesusvico.com.
In winter 2013/2014 I was astonished to see a similar coin (Fig. 3.1) $)^{5}$ in the 2014 March auction catalogue of Roma Numismatics Ltd. ${ }^{6}$ Its weight is $2.84 \mathrm{~g}$, die axis is $5 \mathrm{~h}$, and the obverse inscription is FLAV MAX HELENA AVG. It was minted with different obverse and reverse dies then the coin in the HNM. The existence of different dies could mean that the coins are not imitations, but they are part of a larger issue. The cataloguer assigned the coins to "Helena II", wife of Julian II, and based on its weight he assumed that it was struck at the beginning of her reign. ${ }^{7}$ The auctioned Helena coin stimulated intense discussion on numismatic internet forums $^{8}$, and thanks to this I got to know ${ }^{9}$ a third coin of this type (Fig. 3.2), ${ }^{10}$ which was minted with dies different from the two other ones. This was sold by Jesús Vico, a Spanish art

1 Alföldi 1928, 60, VIII. T. 9.

2 Alföldi 1928, 60, VIII. T. 10-11.

3 cf. RIC III 177.

4 Alföldi 1928, 60-63.

5 For permission to reproduce the photographs I thank Mr. Richard E. Beale, director of Roma Numismatics Limited (www.RomaNumismatics.com).

6 Roma Numismatics Ltd. Auction VII, lot 1321.

7 Roma Numismatics Ltd. Auction VII, lot 1321.

8 E.g.: www.forumancientcoins.com, www.cointalk.com.

9 Post by a user under the nickname "romeman" at the online Forum of Ancient Coins (http://www.forumancientcoins.com /board/index.php?topic=94395.0).

10 For permission to reproduce the photographs I thank Mr. Jesús Vico, Jesús Vico S.A. (www.jesusvico.com). 
dealer in 2002, so chronologically this is the first known coin. The weight, the diameter, and the die axis are not known, even Mr. Vico could not provide more information. Based on the photographs I assume the axis to be $12 \mathrm{~h}$. Allegedly a metallographical analysis had been made on the coin, showing it to be $80.75 \%$ silver, $17.91 \%$ copper and $1.34 \%$ other". ${ }^{11}$ Jesús Vico assigned the coin to the mother Constantine I' and dated it around 310, to the end of the tetrarchic silver (billon) coinage. This can be ruled out as the depicted hairstyle appears only in the mid-320s on the coins of Helena and she received the title Augusta in 325.

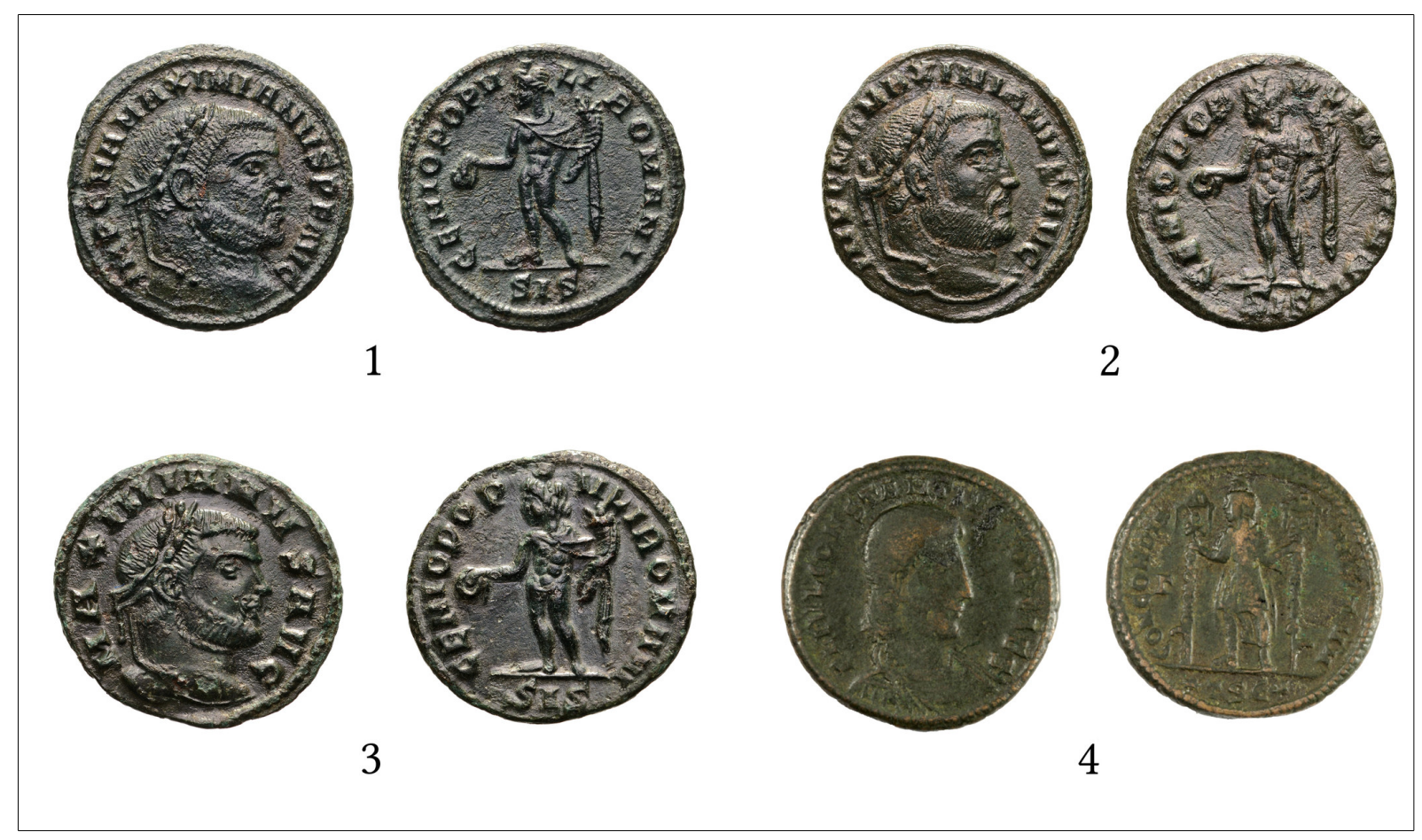

Fig. 4. 1-3. Galerius, laureate fractions. 4. Constantius Gallus, AE2.

As all coins bear the name Flavia Maxima Helena, the question of attribution arose once again. Mixing up or misspelling names is not common on Roman coins, and usually it is due to a mistake committed by the engraver. This cannot be the case, as all three dies are inscribed Maxima instead of Julia. The mistake must have been made by the person responsible for the design of the coin, or the instructions sent to the engraver were erroneous. There are some examples for this. After Constantius Gallus had become Caesar, the mints of Constantius II began minting coins for him as well. In Thessalonica his name is given as FL IVL CONSTANTIVS NOB CAES on coins of the earliest issue: ${ }^{12}$ instead of Claudius the Julius name of Constantius II is used (Fig. 4.4). The error was corrected in later issues. In 305 small bronze coins were minted for the newly elevated emperors in Siscia ${ }^{13}$. Three obverse legend types were minted for the Augusti, for Galerius the following ones: IMP C M A MAXIMIANVS P F AVG, IMP C M A MAXIMIANVS AVG, MAXIMIANVS AVG (Fig. 4.1-3). The first and the second one is clearly the name of Maximian Herculius, the third one is correct for Maximianus and Galerius as well.

11 The metallographical analysis is mentioned in a post by a user under the nickname "romeman" at the online Forum of Ancient Coins (http://www.forumancientcoins.com/board/index.php?topic=943395.0) without any references.

12 RIC VIII, p. 398.

13 RIC VI 146-147, 167-171. 


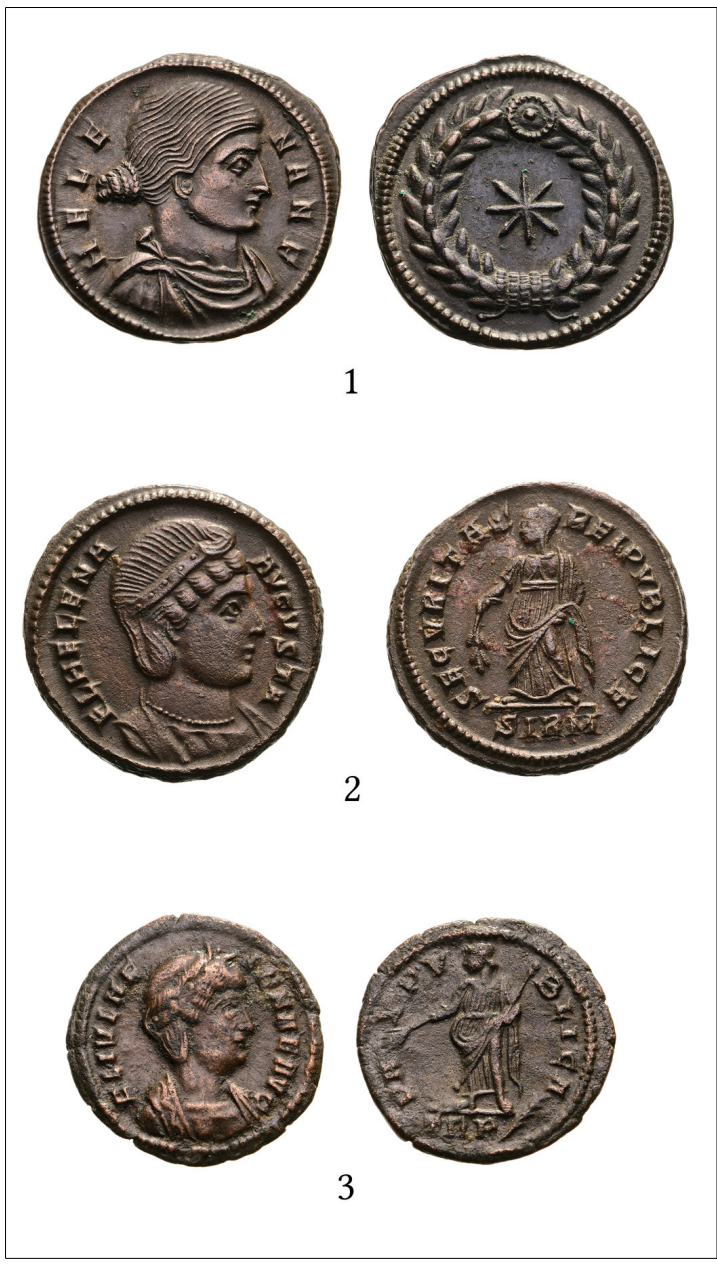

Fig. 5. 1. Helena AE3. 2. Helena AE3. 3. Helena AE4.

Therefore it is possible, that the coins were minted for Flavia Julia Helena, and the names Flavia Maxima Fausta or Flavia Maximiana/Maxima Theodora had influenced the name-form. Theoretically the inverse situation is also possible, that the coins were minted for Fausta or Theodora. On the other hand several arguments can be drawn up against identifying Helena on the coin with the mother of Constantine: the FLAV abbreviation is never used on her coins, apart from two rare Thessalonican issues dated to 318-320. She always wears a necklace. In the early issues her hairstyle is different, her title is not Augusta but Nobilissima Femina, and only her Helena name is represented (Fig. 5.1). In the issues dated 324-329 the title Augusta is never abbreviated, the name is always represented as FL HELENA (Fig. 5.2). The last coins minted for her were issued between 337 and 340 together with the coins of Theodora. Though these are posthumous coins, they are not commemorative ones in the classical sense but had an actual political message after the massacre of most of the male descendants of Constantius I. ${ }^{14}$ The name is always in dative: FL IVL HELENAE AVG (Fig. 5.3).

The silver coins of Helena do not match the style of any of the three periods, moreover compared to those they can be judged being of crude style, they seem to be quite slobbered, as the dies were made in haste.The coins are also special because they bear no mint-mark, which may imply that they were not meant to be a regular currency, but were made for some special occasion. Though metallographical analysis was made on only one coin, its $80 \%$ silver content differs from the $90 \%$ standard of the silver coins in the middle third of the 4 th century. ${ }^{15}$

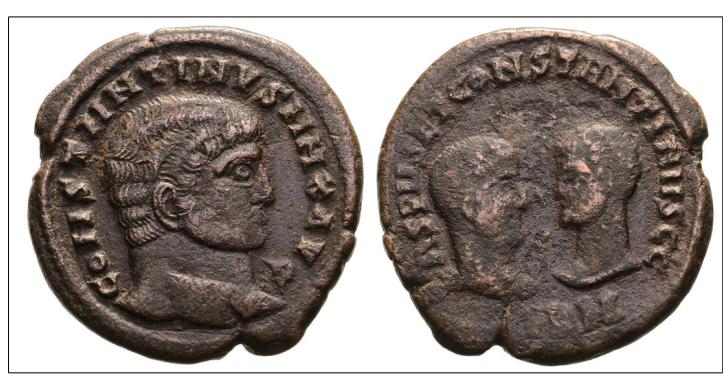

Fig. 6. Constantine I, medallion.
Firm conclusion cannot be drawn from the weight of two coins, especially as the siliquae of the period deviate significantly, but it must be noted, that the two known coin weights $(2.27 \mathrm{~g}$ and $2.84 \mathrm{~g})$ are very different and over the 2.2-1.6 $\mathrm{g}$ average of the period. ${ }^{16}$ This may be paralleled to the silver issue of 320 at Sirmium (Fig. 6), which was minted before the reintroduction of regular silver coinage. The coins were likely intended to be moneta donativa

14 Burgess 2008, 22-24; Woods 2011, 193-194.

15 See note 9.

16 Various results of several measures are given in a chart in RIC VIII, 59. 
or small medallions and not regular currency. I have collected the weight of 32 coins from catalogues and sales, ${ }^{17}$ the great variation of weight is obvious. I do not know of a metallographical analysis made on these coins, but most of them seem to be made of silver, while a few one look like bronze coins. It is very likely that the Helena silver coins were meant to be siliquae, but as they were not regular currency, it is not possible to date them on the basis of weight and silver content.

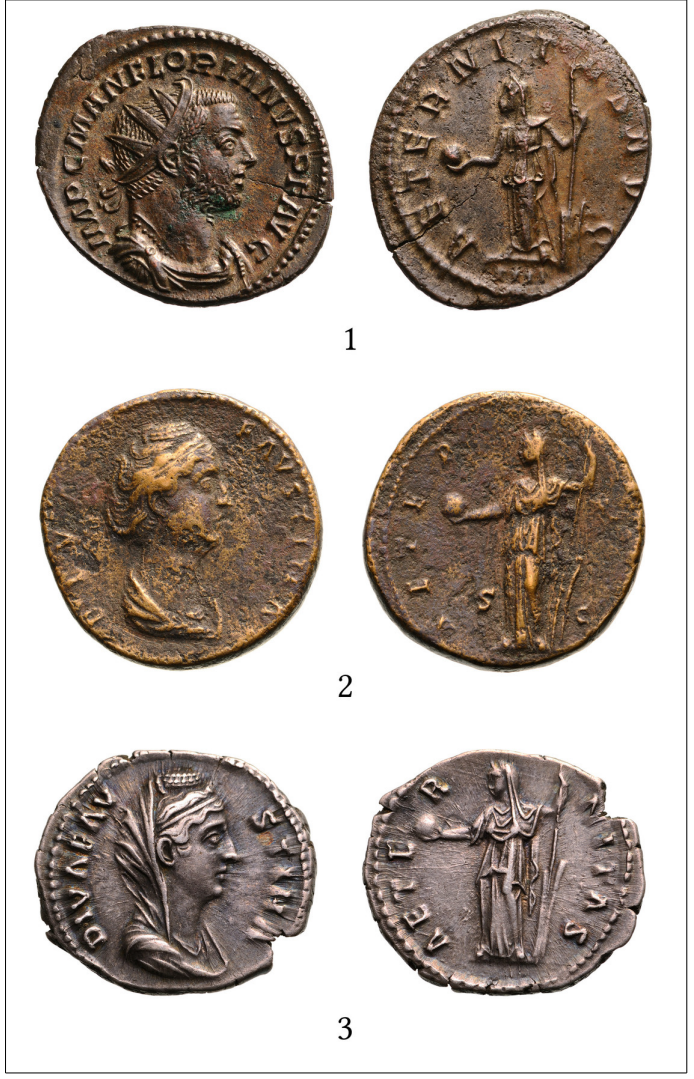

Fig. 7. 1. Florian, antoninian. 2. Faustina Maior, sestertius. 3. Faustina Maior, denarius.
I have found this reverse on the coins of two earlier rulers. On a single type of antoniniani of Florian the reverse legend is AETERNITAS AVG (Fig. 7.1), ${ }^{18}$ and refers to the rule of the emperor; and on sestertii (Fig. 7.2), ${ }^{19}$ denarii (Fig. 7.3$)^{20}$ and aurei ${ }^{21}$ struck by Antoninus Pius for his consecrated wife, Faustina Maior. This time the reverse is not singular, as Antoninus Pius had an extensive coinage for his late wife with many gods, goddesses, and personifications, mostly with the legend AETERNITAS or AVGVSTA.

In the Roman coinage it was not extraordinary to renew earlier types or legends. Most of the time this was made to refer to earlier events, and with these hints the actual message became more emphatic. Based on the similarity of the Faustina Maior coins, I think the Helena coins are rather some kind of commemorative pieces, than ones made for her elevation. Similar coins were struck for Divus Constantinus in Treveri, Lugdunum and Arelate, but their reverse depicts Constantine holding a spear and globe, the legend is AETERNA PIETAS (Fig. 8.1).

There is another coin type, which theme has nothing to do with the Helena coins, but the design is very similar: the SPES REI PVBLICE coins of Constantius II and Julian II. They were struck in silver and bronze, the later in incredible quantity between 358 and 361 in all mints of the empire.

The influence of these coins is visible on two of the coins of Helena. On the Budapest and the London exemplars the original short (military) dress is visible, the left leg is nude, but the end of the long robe is still marked at the ankle, the paddle of the rudder is very crudely cut, trident-like, probably altered from a spear. The obverse depiction is also very strange. On the Madrid coin no drapery is visible, what is unprecedented on female busts. The drapery on the London coin seems to be added to a "head only" portrait. On the Budapest coin

17 The listing is just informative, not exhaustive: $3.87,3.92,3.92,4.08,4.11,4.14,4.19,4.25,4.30,4.304 .33,4.39,4.40,4.41$, $4.48,4.52,4.56,4.61,4.69,4.70,4.70,4.75,4.81,5.00,5.00,5.05,5.20,5.32,5.42,5.42,5.64$, and $5.69 \mathrm{~g}$.

$18 \mathrm{RIC} \mathrm{V/12.}$

19 RIC III 1107.

20 RIC III 348a.

21 RIC III 348a-b. 
the bun and the braid bound up at the back seem to be added posterior to a (probably originally not draped) male bust. ${ }^{22}$ Thus, the coins were likely struck in the late 350 s or early 360s. It is quite improbable that coins were minted for Helena Maior at this time, as real commemorative coins were never made for her, or if such had been struck there is still no reason for the haste and the slobbered work.

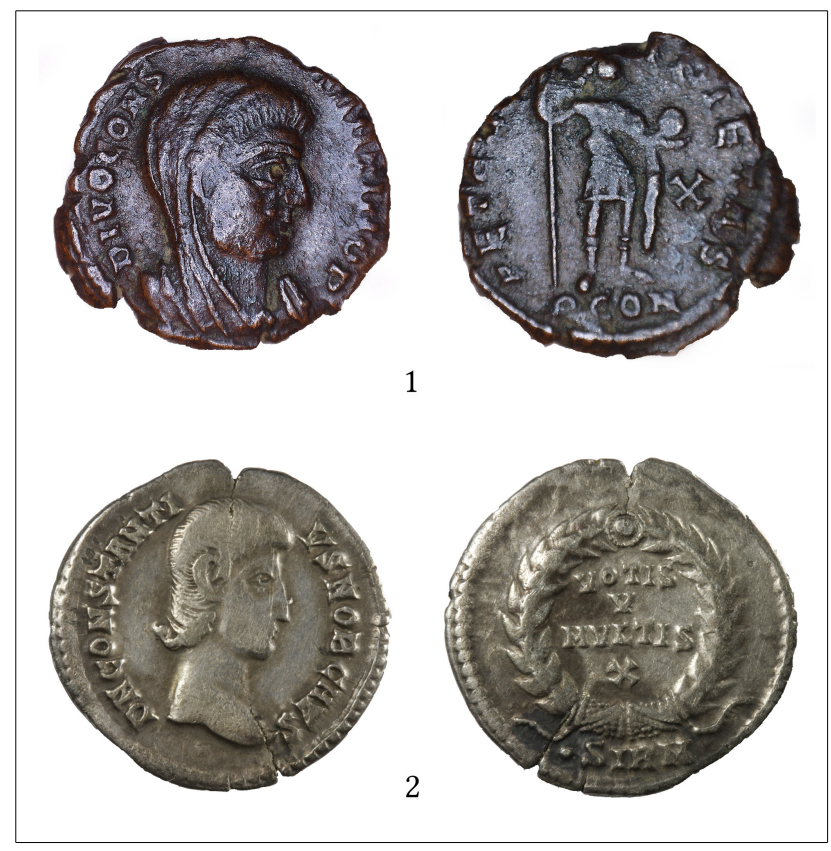

Fig. 8. 1. Divus Constantine I, AE4. 2. Constantius Gallus, siliqua.

There is another Helena in the mid-4th century ${ }^{23}$, the sister of Constantius II and the wife of Julian II, whom the coins might have been minted to. She is very little known. She married Julian II after his elevation to the rank of Caesar on the 6th November 356. She followed her husband to Gaul, in 357 she was present on the vicennalia of Constantius II in Rome. She had several miscarriages. She died in 360 or very early 361 , by the time of the quinquennalia of Julian II she was already dead. Her full name is unknown, she is mentioned Helena in the sources. However the name Flavia Maxima Helena is quite probable, as her mother was Flavia Maxima Fausta, and her niece, daughter of Constantius II was called Flavia Maxima Constantia.

The personality of Julian II may help to explain this peculiar issue. Julian truly loved her wife, after her death he had no relation to any woman. This love might have motivated the issue and the choice of the reverse, linking the issue to the most extensive commemorative coinage. Choosing Fortuna may also represent the personal beliefs of the emperor, his acquiescence.

Presumably the coins were made for the funeral, that is why they had to be minted in a haste. In this case Rome seems to be the most probable minting place, as Helena was buried by Via Nomentiana next to her sister Constantina, wife of Constantius Gallus. On the other hand the style of the coins is very different, so several mints are also admissible.

22 The bust type resembles the bust of Constantius II, Constantius Gallus and Constans (Fig. 8.2).

23 There are certainly many more Helenas in the 4th century, for instance the wife of Crispus, but assigning the coins to them is quite improbable. 


\section{References}

AlFöLDI, A. 1928: Materialen zur Klassifizierung der gleichzeitigen Nachahmungen von römischen Münzen aus Ungarn und den Nachbarnländern. - Anyaggyüjtés a római pénzek Magyarországon készült egykorú utánzatainak osztályozásához. Numizmatikai Közlöny XXVI-XXVII (1927-1928) 59-71, VIII-IX t.

Burgess, R. W. 2008: Thhe Summer of Blood: the "Great Massacre" of 337 and the Promotion of the Sons of Constantine. Dumbarton Oaks Papers 62, 5-51.

RIC III: Mattingly, H. - Sydenham, E. A.: The Roman Imperial Coinage Vol. III. Antoninus Pius to Commodus. London 1930.

RIC V/1: WebB, P. H.: The Roman Imperial Coinage Vol. V. Part I. London 1927.

RIC VIII: Kent, J. P. C.: The Roman Imperial Coinage Volume VIII. The Family of Constantine I AD 337364. London 1981.

Woods, D. 2011: Numismatic Evidence and the Succession to Constantine I. The Numismatic Chronicle 171, 187-196, Plate 26.

\section{List of illustrations}

Fig. 1. Hungarian National Museum. Photo: Csaba Gedai

Fig. 2. After Alföldi 1928, VIII.t.

Fig. 3. 1. www.RomaNumismatics.com 2. www.jesusvico.com

Fig. 4. Hungarian National Museum. 1-3. Photo: Csaba Gedai. 4. Photo: Dávid Bartus

Fig. 5-7. Hungarian National Museum. Photo: Csaba Gedai

Fig. 8. Hungarian National Museum. 1. Photo: Tamás Szabadváry 2. Photo: Dávid Bartus 